This Section of Epidemiology and Psychiatric Sciences appears in each issue of the Journal and is dedicated to all forms of creative production born of an intimate and individual urge, often secretive, unbound from the conventional art system rules. Through short descriptions of the Outsider art work of prominent artists and new protagonists often hosted in community mental health services, this Section intends to investigate the latest developments of the contemporary art scene, where the distances between the edge and the centre are becoming more and more vague.

Carole Tansella, Section Editor

\title{
Antonio Dalla Valle's soft code
}

\section{Tansella}

Department of Time, Space, Image, Society, University of Verona, Verona, Italy

Received 23 May 2013; Revised 23 May 2013; Accepted 23 May 2013; First published online 5 July 2013

Key words: Outsider art, Art brut, Self-taught art, Contemporary aesthetic.
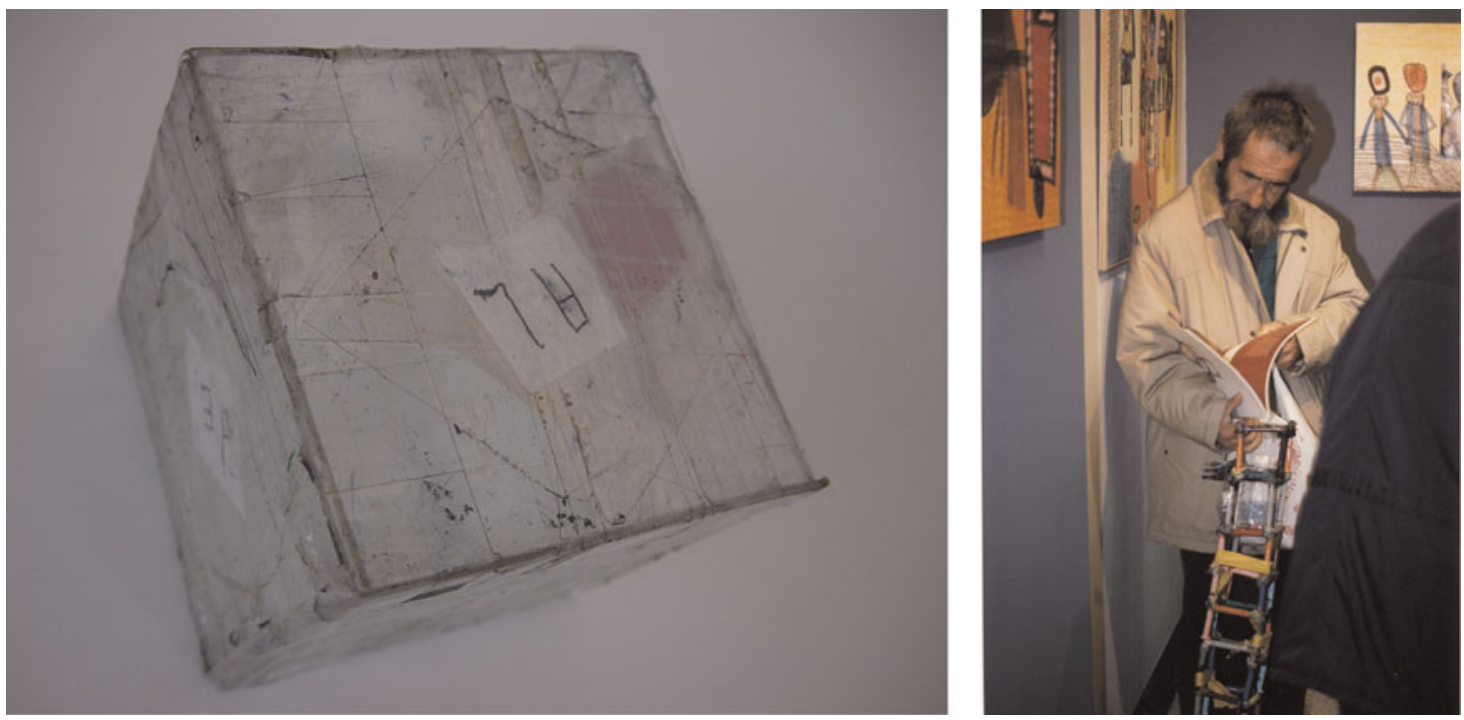

On the left: Antonio Dalla Valle: Plexiglas cube, mixed media, 1999-2000, $12 \times 12 \mathrm{~cm}$, Collection Sospiro. On the right: Photo of the artist at the opening of the exhibition 'ArteOltre', Museo Civico Ala Ponzone, Cremona, 2002. Full colour versions available as online supplementary material. http://dx.doi.org/10.1017/S2045796013000309

Antonio Dalla Valle was born in 1939 in Cles and spent his childhood in Roncio, a small mountain village in the province of Trento, in northern Italy. We know

Address for correspondence: Dr Carole Tansella, Department of Time, Space, Image, Society, University of Verona, Via San Francesco 22, 37129 Verona, Italy.

(E-mail: carole.tansella@yahoo.it, carole.tansella@univr.it) that he comes from a family of limited economic means and that as a child, he was not given much love or attention. After attending a bricklayer course, at the age of 20 years he moved to Germany, where he found a job. His working experience abroad proved to be hard, and in 1962 he came back to Italy before being admitted to the psychiatric hospital in Pergine, in the province of Trento (Gossetti, 2006). From that 
moment on, Dalla Valle was hospitalized in several psychiatric institutions until 1997, when he was permanently admitted to the Sospiro Foundation in the province of Cremona.

In 1995, the Sospiro Foundation opened an art studio run by Paola Pontiggia, called La Manica Lunga Officina Creativa. It is a space where the patients of the institution are encouraged to experience their creativity, the place where Dalla Valle could give a new start to his new life. He had been a victim of the misunderstandings of the therapeutic employees for years, who considered the outcomes of his drawing, writing, sculpting and collecting a 'pile of meaningless stuff' (Tosatti, 2002). Following an encounter with Paola Pontiggia, who is a recognized artist, Dalla Valle's talent was finally acknowledged. Pontiggia engaged in the conservation and in the systematic cataloguing of his works, creating a permanent exhibition within the art studio, available for visits, and managing the exhibitions as well as the loans of the art work of Dalla Valle and his peers. Meanwhile Dalla Valle, free from any issues related to the traditional art organization and inspired by this strong human and working relationship, carried on creating new works (Pontiggia, 2007).

Dalla Valle's works share some of the typical art trends of the Nineties, such as the use of everyday materials and the blending of creative reflexions with autobiographic narration; and maybe for this reason his works have been culturally acknowledged only when the public's gaze proved to be sufficiently ready to understand him.

The starting point of Dalla Valle's works is completely focused on concepts and on dematerialization. His frenetic writing activity on notebooks full of numbers and drawings was attested to in his clinical dossiers since his very first admission to hospital. These are manuscripts that will become paper blocks wrapped with cellophane, which, before coming to the atelier, Dalla Valle used to destroy.

A representative work of Conceptual Art is One and Three Chairs made in 1965 by Joseph Kosuth. In this work a picture of a chair and an enlargement of the dictionary entry 'chair' are lined up with a real chair. This is the representation of the three new logics of art that will supplant the typical ones of traditional art. The photographic representation, the concrete object or 'readymade', and the linguistic element are solutions which go beyond the formal and concrete boundaries of the former art (Kosuth, 2003). Of this new model presented by Kosuth, Dalla Valle chooses to follow the linguistic trend, by interpreting it in a more personal and warm way relying on his personal handwriting. After all, the years in which the new artistic standard had to be in a strong position in order to win over the public has already passed, and therefore the most severe aspects are now mitigated by the artists of the new generation.

Dalla Valle's mental solicitations are expressed in formulae of symbols and numbers, too rich of information and details to be decoded by neophytes. It can be discouraging to try to understand his expressions of mathematical ideas, as they are too abstract to be figured out if compared with everyday language. His work leaves the public speechless. With the passing of time these formulae become softer, and we see a more harmonic presence of conceptual aspects along with sensorial stimulation. For instance, we can see how the written pieces of cardboard are replaced by a series of obelisks made by rolled sheets covered with tape, inserted in other tubes made of written paper until creating some obelisks.

The process of exploiting materials is more evident in the Plexiglas cubes series. The heart of these airtight containers is made up of written elements, combined with everyday materials such as fabrics, coloured ribbons and personal objects.

The charm of handicraft and the visual, tactile and olfactory stimulation of the series of grills prevail on the chasing game between mathematical restrictions and sensorial pleasure. It is a series of sculptures, conceived with a long and rigorous process, which consists of a structure of markers of different colours, which have been emptied and fixed together in order to create a tower-like structure.

Dalla Valle uses simple objects in his work, objects taken from the everyday life. They are part of the existence of all of us, to tell the same story, always his own tale. These minimal installations, which keep traces of his autobiography and which record some of the most prominent moments of the artist's life, are paradoxical linguistic-sculpted devices, as they baffle common decoding criteria. The voyeuristic curiosity of the viewer, tricked by the familiarity of the materials, is floored by the obscure and sophisticated nature of the works. These art pieces do not strive to be understood. The artist's notebooks cannot be explained and the cubes are obscure from every point of view, yet we feel a strong reference to our intimate life. We can feel that these objects do not just tell something about Dalla Valle, but also something about us.

Recently Antonio Dalla Valle took part in several National and International exhibitions such as: ArteOltre, Museo Civico Ala Ponzone, Cremona, 2002; Outsider Art Italia, Finarte-Semenzato, Milan, 2003; Ecritures Imagées, Art \& Marge, Bruxelles, 2004; Personale, Mad Musée, Liège, 2004; Vision Singuliéres, Palais de Bozar, Bruxelles, 2005; 
Cardiogramme, Mamac, Liège, 2007; Stupefatti di Spazio, ex-cappellificio Luigi Rossi, Carpi, 2008; Due ma non Due, Loggia della Mercanzia, Genoa, 2008; $2 \times 2$, Kunsthaus Kannen, Münster, 2009; Liaison Insolites, Art \& Marge, Bruxelles, 2010; Intelligenze Rovesciate, Fortezza del Primar, Savona, 2011; Capogiro, Galleria d'arte Moderna e Contemporanea, San Marino, 2012; Banditi dell'Arte, Halle Saint Pierre, Paris, 2013.

Dalla Valle is the subject of several monographs both in Italian and French, and his works are permanently exhibited in Sospiro, by the Sospiro Foundation; at the Musée de l'Art Brut in Lausanne; in the Menozzi Collection in Reggio Emilia; at the Mad Musée of Liège as well as in the Art Collection \& Marge in Bruxelles.

\section{Supplementary materials and methods}

The Supplementary material referred to in this article can be found at http://dx.doi.org/10.1017/ S2045796013000309.

\section{References}

Gossetti C (2006). Antonio Dalla Valle. Il Ritorno. Catalogo della mostra. Mezzana.

Kosuth J (2003). L'arte Responsabile. Quaderni della Scuola di Specializzazione in Storia dell'Arte, n.3, Università di Bologna, Compositori: Bologna.

Pontiggia P (2007). Antonio Dalla Valle. Figure Blu. Fondazione Sospiro: Sospiro.

Tosatti B (2002). Arte Oltre. Catalogo della mostra. UTET: Torino. 